\title{
Minapadi productivity with a combination of legowo technology and local fish
}

\author{
Farah Diana $^{1 *}$, Mahendra Mahendra ${ }^{1}$ and Giovanni Oktavinanda ${ }^{2}$ \\ ${ }^{1}$ Aquaculture Study Program, Faculty of Fisheries and Marine Science, Teuku Umar University, West Aceh, Indonesia \\ ${ }^{2}$ Marine science Study Program, Faculty of Fisheries and Marine Science, Teuku Umar University, West Aceh, Indonesia
}

\begin{abstract}
Minapadi is a fish rearing system in rice fields that is carried out with rice plants. This study aims to increase the income of farmers with high productivity of rice yields and increase the production of endemic fish. The method used was a Completely Randomized Design (CRD) experiment with four treatments and 3 replications. PThe treatments are: A1B1 (Legowo 2:1 and giant prawns), A1B2 (legowo 2:1 and fish serukan), A2B1 (legowo 4:1 and giant prawns), and A2B2 (legowo 4:1 and fish serukan). This research was conducted for 90 days in the rice fields of Lango Village, Pante Ceureumen District, West Aceh Regency. Parameters observed were rice productivity, fish growth and business analysis. The results showed that the best treatment was A1B1 (4:1 legowo and giant prawns) with generate value rice productivity average as big as $5 \mathrm{~kg} / \mathrm{plot}$, and the average value of the growth of giant prawns is $3.62 \mathrm{~g} / \mathrm{head}$ and fish serukan is $37.17 \mathrm{~g} / \mathrm{h}$ ead. From the results of this study, the application of the Minapadi system with giant prawns and fish with legowo 4:1 gave a positive impact on the observed parameters $(\mathrm{P}<0.05)$, annd provide benefits to farmers.
\end{abstract}

\section{Introduction}

Diversity the life of freshwater fish in Indonesia, especially Sumatra today facethreats from various factors anthropogenic which can cause a decrease in the diversity of native fish in the waters [1]. Fish farming businesses in Aceh Province have begun to develop, howeversadly The types that are kept are foreign fish introduced from outside Aceh and evenoutside the country. This condition puts pressure on the local native fish population. Meanwhile, Aceh also has the potential for native fish that are not inferior both in terms of quantity and quality, for example giant prawns (Macrobrachium rosenbergii) [2] and serukan (Osteochilus Vittatus) [3]. The research team has also succeeded in developing and producing local fish including producing Tawes fish (Barbonymus gonionotus) [4], fish serukan.

The rapid increase in population can cause more limited large areaproduction that can be used for various fields of fishery business, it is necessary to utilize the existing land through intensification. One way that can be done is by implementing the minapadi system.

The jajar legowo planting system in minapadi provides a loose growing space as well as a higher population. With this planting system, it is able to provide air circulation and better utilization of sunlight for planting. Besides therefore, weed control and fertilization efforts can be done more easily. The best type to get minapadi performance is $2: 1$ and $4: 1$ [5]

The potential for developing minapadi cultivation is still very wide. Potential data which released by the directorate general of aquaculture, nationally land use for cultivation minapadi only amounted to 127,944 hectares of the potential land area of 1,538,379 hectares. So, the level of land use for rice cultivation is only about 8.3 percent. Therefore, the Ministry of Marine Affairs and Fisheries through the Directorate General of Aquaculture has again promoted the minapadi cultivation program to support the target of aquaculture production [6]

Based on the above, the author is interested in conducting a research entitled "minapadi productivity with a combination of legowo technology and local fish". The purpose of this study was to determine whether the use of different combinations of the legowo system and Aceh endemic fish had an effect on minapadi productivity and which combination was the best for minapadi productivity.

\section{Research Methods}

\subsection{Research sites}

This research was conducted in the rice fields of Pante Ceureumen District, West Aceh Regency from preparation to data collection.

\subsection{Experimental design}

The method used in this study is an experimental method and the design used is a Completely Randomized Design (CRD) consisting of four treatments with 3 replications

\footnotetext{
*Corresponding author: farahdiana@utu.ac.id
} 
each. The treatment of each material used in this study includes:

The method used in this study is an experimental method and the design used is Completely Randomized Design (CRD). The two factorial was repeated three times.

Factor first tested are:

A1 = legowo system 2: 1

A2 = legowo system $4: 1$

The second factor is:

B1 $=$ Giant prawns

$\mathrm{B} 2=$ Fish serukan

Combination There were 4 treatments in total, namely: A1B1, A1B2, A2B1, A2B2.

\subsection{Research procedure}

This research was conducted in rice fields with a total of 9 plots with an area per plot of $5 \times 10$ meters. Make a rice field bund with a height of $60 \mathrm{~cm}$, a base width of $60 \mathrm{~cm}$ and an upper width of $30 \mathrm{~cm}$. While the trench (kemalir) according to the legowo system treatment with the size: $30-60 \mathrm{~cm}$ wide, $40 \mathrm{~cm}$ deep. Planting is done by transplanting (Tapin). Rice is planted after 30 days. The variety used is resistant to waterlogging and pest attack, namely MAPAN. Spacing $25 \times 12.5 \mathrm{~cm}$. The number of seedlings planted $2-3$ stems per clump. The water level is $10 \mathrm{~cm}$. Shrimp stocking was done when the plants were 30 days old with a water level of $10 \mathrm{~cm}$.

Stocking density was carried out according to the treatment. Stocking is done in the afternoon to avoid stress fish. The length of shrimp rearing in the Minapadi system is 90 days with feeding 3 times a day, namely in the morning, afternoon and evening. The maximum dose given is $3 \%$ of the total biomass with the frequency of administration. Shrimp harvest is done 90 days after planting rice. Observation of rice seen from its productivity. While shrimp and fish are seen from their growth.

\subsection{Research Parameters}

\subsubsection{Rice productivity}

Productivity rice according to [7] is calculated using the formula:

Rice Productivity $=\frac{\text { Production quantity }(\mathrm{Kg})}{\text { land area }(\mathrm{ha})}$

\subsubsection{Absolute Weight Growth}

The calculation of absolute weight growth uses the following [8] formula:

$W=W_{t}-W_{0}$

where, $\mathrm{w}$ is growth absolute weight $(\mathrm{g})$; wt is final weight of maintenance $(\mathrm{g}) \mathrm{w}_{0}$ is initial weight of maintenance $(\mathrm{g})$.

\subsection{Analysis Data}

The data obtained will be grouped, tabulated, performed statistical tests ANOVA and SPSS to see the effect of the experiment. If there is a significant difference, Tukey's further test will be carried out.

\section{Results and Discussion}

\subsection{Rice productivity}

Based on the results of the ANOVA which showed that the combination of legowo technology and local fish had no significant effect $(\mathrm{P}>0.05)$ on minapadi productivity. The results obtained from this study during 90 days of maintenance can be seen in Figure 1.

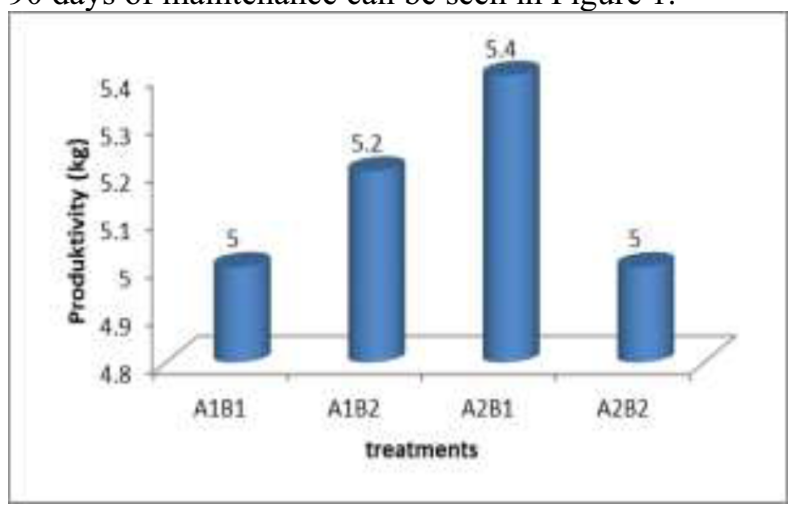

Fig.1. Rice Productivity

Productivity is the process of converting factors of production into a product. Productivity reflects the ratio between total production and land area. The results of the study based on Figure 1 show that the highest rice productivity value in this study was A2B1 treatment (Legowo 4:1 with giant prawns) with an average value of $5 \mathrm{~kg} /$ plot. According to research by [9] that through Minapadi there was an increase in land productivity from $5,652 \mathrm{~kg} / \mathrm{ha}$ to $7,612 \mathrm{~kg} / \mathrm{ha}$. The area of rice and Minapadi is the same, but the proportion of Minapadi is $90 \%$ for rice cultivation and $10 \%$ for fish cultivation.

According to [10], Minapadi cultivation is said to be successful when rice production is at least the same as production before Minapadi. The ability of land in production is getting better when implementing Minapadi. Efforts to increase productivity are achieved through improving soil conditions and intensive handling of pests and weeds.

The high productivity of rice in the $\mathrm{A} 2 \mathrm{~B} 1$ treatment is suspected to be the pellet feed given is not consumed by shrimp where the pellets used are the trademark FF999 for fish, so that shrimp prefer abundant natural feed. The remaining pellets will accumulate into fertilizer which is absorbed by the rice plant. According to [11] Nitrogen is the main nutrient for plant growth, nitrogen is absorbed by plant roots in the form of NO3 (nitrate) and $\mathrm{NH} 4+$ (ammonium). Nitrogen deficiency can be bad for plants such as stunted plant growth, yellowing of plant leaves, and limited root system, while excess nitrogen causes vegetative growth to be elongated, easy to fall, reduce grain quality and response to pests and diseases. 


\subsection{Giant Shrimp Growth}

The growth results of giant prawns in each treatment for 90 days of rearing period are presented in Figure 2.

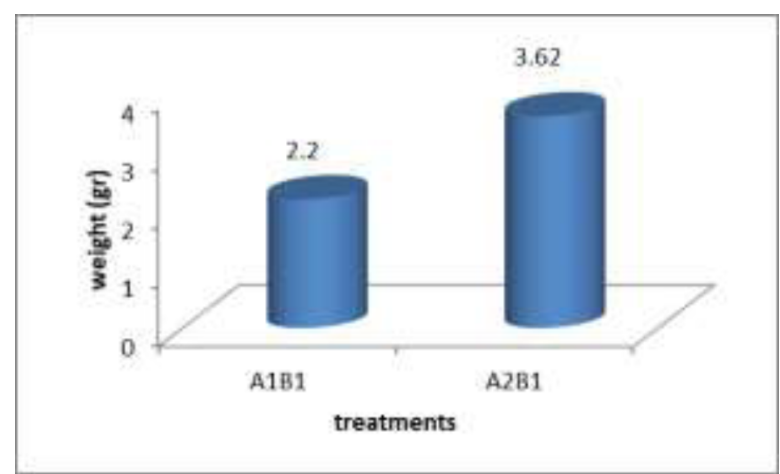

Fig.2. Growth of giant prawns

The results of the study based on Figure 1 showed that the lowest growth value in this study was A1B1 treatment (Legowo 2:1 with giant prawns stocking) with a value of 2.2 gr. Meanwhile, the highest growth value was found in the A2B1 treatment (4:1 legowo with giant prawns stocking) with a value of 3.62 gr. The results of this study indicate that the A2B1 treatment plays a role in supporting the growth of giant prawns.

Some aspects of physiological processes related to individual growth include regeneration, metamorphosis and moulting. Moulting is the process of periodically releasing old shells and forming new, larger shells. In crustaceans, growth occurs periodically after molting. Body weight gain will be hampered if it is not preceded by the molting process (Affandi and Tang, 2002).

High growth is characterized by a faster molting process. The process of energy transfer from hemolymph to shrimp shell requires a large amount of energy. This large energy requirement is obtained from the feed consumed. Feeding is an energy requirement to support faster growth. This is closely related to growth where if feed consumption is high, there is a lot of energy available that can be used for various life needs and by reducing energy expenditure, so that the portion of energy available for growth is greater. If the physiology of shrimp goes well, including metabolism, then the utilization of feed is more efficient which ultimately increases growth [12]. Therefore, the legowo 4:1 system is more suitable for growth, because of the protection of the rice plant 4 .

\subsection{Fish Growth}

The results of the growth of fish in each treatment during the 90-day rearing period are presented in Figure 3.

The results of the study based on Figure 3 it was found that the growth value of the fish serukan was related to the shrimp where the lowest value in this study was the A1B2 treatment (Legowo 2:1 with the distribution of the serukan) with a value of $26.48 \mathrm{gr}$. Meanwhile, the highest growth value was found in the A2B2 treatment (4:1 legowo with fish serukan) with a value of $37.17 \mathrm{gr}$. The results of this study indicate that the $\mathrm{A} 2 \mathrm{~B} 2$ treatment plays a role in supporting the growth of the fish.

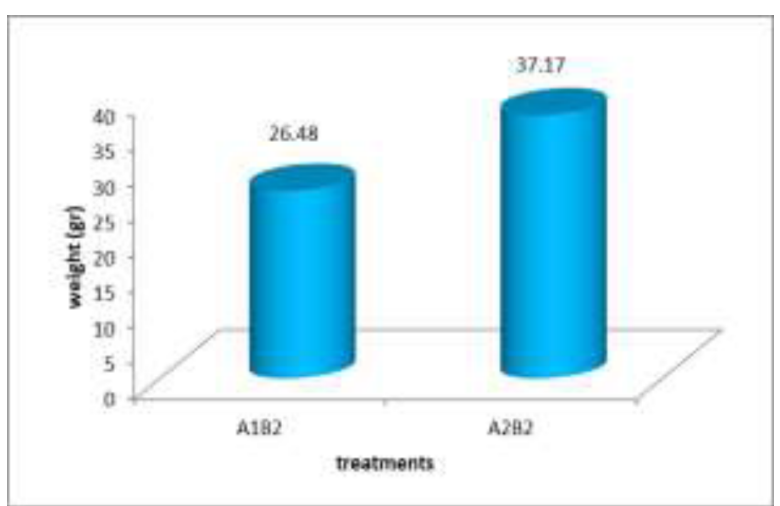

Fig.3. Fish Growth

The growth of fish and shrimp in Minapadi and Legowo systems was higher with Legowo 4:1 compared to Legowo 2:1. It is suspected that the protection of the legowo 4:1 system of rice plants is more maximal compared to the legowo $2: 1$ and it is also suspected that the number of kemalir 4 : is less, so that the activity of fish such as swimming is reduced, therefore less energy is spent. Feeding is an energy requirement to support faster growth. This is closely related to growth where if feed consumption is high, there is a lot of energy available that can be used for various life needs and by reducing energy expenditure, so that the portion of energy available for growth is greater. If the shrimp physiology goes well, including metabolism.

\subsection{Analysis Farmers' income}

Minapadi system farming analysis for farmers needs to be done to find out how much added value can be obtained from the business, then economic analysis is part of finding out whether the system is feasible or not to be developed and to find out whether the Minapadi system provides benefits or not. So below, a simple analysis of the Minapadi farming system applied can be seen in Tables 1 and 2.

Table 1. Rice production results from the legowo Minapadi system

\begin{tabular}{|c|c|c|c|c|}
\hline Model & $\begin{array}{c}\text { Rice } \\
\text { Production } \\
{[13]}\end{array}$ & unit & $\begin{array}{c}\text { Rice } \\
\text { Production } \\
\text { (processed } \\
\text { data) }\end{array}$ & Unit \\
\hline Legowo 2:1 & $3.04 \mathrm{a}$ & ton $/ \mathrm{ha}$ & 5.1 & $\mathrm{Kg} / 50 \mathrm{~m} 2 \mathrm{a}$ \\
\hline Legowo 4:1 & $2.94 \mathrm{a}$ & ton $/ \mathrm{ha}$ & 5.2 & $\mathrm{Kg} / 50 \mathrm{~m} 2 \mathrm{a}$ \\
\hline
\end{tabular}

The assumption of income from the Minapadi system fish farming business is that farmers need $60 \mathrm{~kg}$ of pellets each to raise fish and shrimp. The price of 1 sack of $30 \mathrm{~kg}$ pellets is Rp. 200,000. If the farmer uses $100 \%$ pellets for feed, the cost required is $(60 \mathrm{~kg} / 30 \mathrm{~kg}$ x Rp. $200,000=$ Rp. 400,000). The cost of the farmer's profit if the results obtained are $60 \%$, the cost of income minus the cost of expenses. Where if the assumption of expenditure costs includes the price of 250 giant prawns at a price of @ 500, as much as Rp. 125,000. so that the 
total assumption issued for giant prawns is (Rp. 400,000 + Rp. $125,000=$ Rp. 525,000). While the assumption that the results of the expenditure on the fish of chorus includes 250 fish with a price of @ 1000 , as much as Rp. 250,000 so that the total assumption issued is (Rp. $400,000+$ Rp. $250,000=$ Rp. 650,000$)$.

Farmers' incomes other than rice yields are assumed to yield $60 \%$ of the stocking density of 150 shrimp and fish each with a yield range of 20 per kilogram of shrimp, so the final yield of shrimp is $7.5 \mathrm{~kg}$, with a selling price of Rp. .185.000/kg (Coal and Gustianty. 2016). The total selling price for shrimp is $(7.5 \mathrm{~kg} \mathrm{x}$ $185,000 / \mathrm{kg}=$ Rp. $1,387,500$. So the total profit income for shrimp is (Rp. $1,387,500-R p .525,000=R p$. 862,500 . While for fish with $60 \%$ yields, fish with a yield range of 10 per kilogram of fish, the final yield of fish is $15 \mathrm{~kg}$, with the selling price of fish Rp. $60,000 / \mathrm{kg}$ (local market price) The total selling price of fish is (15 kg x Rp. $60,000 / \mathrm{kg}=$ Rp. 900,000 . So the total profit income for fish is (Rp. 900,000 - Rp. 650,000 = Rp. 250.

The results above are for 1 rice field plot measuring $5 \mathrm{x} 10 \mathrm{~m} 2$, so that the results of this study are 16 plots of rice fields ( 8 plots for shrimp and 8 plots for fish). Therefore, the results obtained by farmers other than rice ranged, among others, for shrimp (Rp. 862,500 × 8 $=$ Rp. 6,900,000). As for fish it is (Rp. 250,000 x $8=\mathrm{Rp}$. $2,000,000)$

So, the total that farmers get is (Rp. 6,900,000+ Rp. $2,000,000=$ Rp. 8,900,000), these results are in addition to the rice harvest. Farmers' profits can be large if the Minapadi system is applied with a large and wide number of rice fields, so that the stocking density is higher.

Table 2. Rice production results from the legowo Minapadi system

\begin{tabular}{|c|c|c|c|c|}
\hline Details & Unit & Amount & Price per unit & Total \\
\hline Variable Cost & & & & \\
\hline Fish seeds & Tail & 250 & 500 & 125,000 \\
\hline Rice Seeds & $\mathrm{kg}$ & 5 & 100,000 & 500,000 \\
\hline Feed & Sak & 2 & 200,000 & 400,000 \\
\hline Fertilizer & $\mathrm{kg}$ & 15 & 10,000 & 150,000 \\
\hline & & & & $1,175,000$ \\
\hline Shrinkage & $\%$ & 20 & & 235,000 \\
\hline Production & & & & - \\
\hline Fish & $\mathrm{kg}$ & 7.5 & 185,000 & $1,387,500$ \\
\hline Paddy & $\mathrm{kg}$ & 5 & 10,000 & 50,000 \\
\hline & & & & $1,437,500$ \\
\hline Profit & & & & 27,500 \\
\hline
\end{tabular}

\section{Conclusion}

Minapadi's 4:1 legowo system has an effect on the growth of giant prawns and fish serukan.with generate value rice productivity average as big as $5 \mathrm{~kg} / \mathrm{plot}$, and the average value of the growth of giant prawns was 3.62 $\mathrm{g} / \mathrm{head}$ while the growth of fish was $37.17 \mathrm{~g} / \mathrm{head}$.
Acknowledgments. The author's research was funded by internal research grants from Teuku Umar University, especially LPPM and Quality Assurance as well as the Aquaculture Study Program, Faculty of Fisheries and Marine Sciences.

\section{References}

1. HasriI, M.M. Kamal and Zairion, J Ichthyol, 11(1), 2010)

2. Erlangga, J Terubuk 44(1), (2016)

3. DKP Aceh, Identification of Endemic Fish Species in Aceh Waters South West Region (West Aceh) (2015)

4. F. Diana, and E Safutra Journal of Aquaculture 2(1), (2018)

5. J. Bobihoe, The Legowo Jajar Rice Planting System (2013)

6. KKP, Minapadi System Fish Cultivation. Directorate General of Aquaculture (2018)

7. E. Silamat, Yuwana, and M.Z. Yuliarso, Analysis of Paddy Rice Farming Productivity Using Hand Tractors and Conventional Methods in Rejang Lebong Regency, (2014)

8. R. Affandi, U.M. Tang, Physiology of Aquatic Animals (2002)

9. D.R. Julistia, Analysis of Minapadi Farming Income in Margoluwih Village, Seyegan District, Sleman Regency, (2017)

10. L.F.I. Tysno, LFI, Analysis of Minapadi Farming Income, (2018)

11. E. Kaya, Agrologia, 2(1), (2013)

12. A.B. Zaidy. Utilization of Aquatic Calcium in the Molting Process and Its Consequences for the Growth of Giant Prawns (Macrobrachium rosenbergii de Man) (2007)

13. I.M Sudiarta, E. Syam'un, and R. Syamsuddin, J. Science \& Technology, 16(1), (2016) 